\title{
Kobiety w czasie Wielkiej Wojny
}

\author{
Wywiad z Françoise Thébaud przeprowadzony w języku francuskim \\ przez Annę Branach-Kallas* i Piotra Sadkowskiego ${ }^{* *}$ \\ Tłumaczenie: Piotr Sadkowski
}

DOI: http://dx.doi.org/10.12775/LC.2018.037

Françoise Thébaud, profesor historii na Uniwersytecie w Awinionie, związana z Instytutem Badań Genderowych Uniwersytetu Genewskiego, jest specjalistką w dziedzinie historii społecznej, autorką pionierskich prac na temat sytuacji kobiet podczas I wojny.

Redaktorzy: Chcielibyśmy przybliżyć polskim czytelnikom kilka tez przedstawionych $\mathrm{w}$ Pani przełomowej pracy $\mathrm{z}$ roku 1986 La femme au temps de la guerre de $14^{1}$ (Kobieta w czasie wojny roku 1914). Zaznacza w niej Pani Profesor, że wojna była szczególnie ciężkim doświadczeniem dla kobiet ze społeczności wiejskich. Czy mogłaby Pani wyjaśnić to zjawisko?

Françoise Thébaud (dalej F. T.): Francja w przededniu Wielkiej Wojny jest jeszcze krajem wiejskim (ponad połowa ludności mieszka na wsiach) i w bardzo znacznej mierze rolniczym. Więcej niż czterdzieści procent Francuzów czynnych zawodowo pracuje w tym sektorze, z czego kobiety stanowią tu ponad jedną trzecią. Sytuacja społeczna ludzi na wsi jest bardzo zróżnicowana, ale nie mogą oni uniknąć mobilizacji i na ogół trafiają do oddziałów piechoty, a więc do formacji najbardziej narażonych na śmierć. Ponadto armia rekwiruje zwierzęta (konie, woły, osły) do różnych zadań w rejonie frontu. Kobiety, do których premier francuskiego rządu wystosował apel 7 sierpnia 1914 roku, aby dokończyły żniwa i przygotowały zbiory, muszą zastępować jednocześnie nieobecnych mężczyzn i zarekwirowane zwierzęta. Dlatego są naprawdę przeciążone obowiązkami. Zgoda na tzw. przepustki rolnicze, o które ubiegają się żołnierze, aby móc pomagać w ciężkich pracach polowych, jest rzadko udzielana. Jednakże wiejskie kobiety korzystają z obiegu gotówki pochodzącej z zasiłku przyznawanego żonom zmobilizowanych żołnierzy i mogą kupować niektóre to-

* Profesor nadzwyczajny w Katedrze Filologii Angielskiej Uniwersytetu Mikołaja Kopernika w Toruniu. Jej zainteresowania badawcze obejmują: literackie obrazy wojny, literaturę postkolonialną oraz komparatystykę. E-mail: kallas@umk.pl.

" Dr hab., adiunkt w Katedrze Filologii Romańskiej Uniwersytetu Mikołaja Kopernika w Toruniu. Jego badania koncentrują się na współczesnych literaturach francuskojęzycznych. E-mail: piotr.sadkowski@umk.pl.

1 Zob. Thébaud, Françoise 1986. La femme au temps de la guerre de 14. Paris: Stock. 
wary w miastach. Inflacja cen jest również dla nich korzystna. Tak jak i inne żony żołnierzy, chłopki cierpią samotność i obawiają się o życie swoich mężczyzn w wojsku. Nigdy nie pisały one tak dużo listów, jak w czasie wojny. Jest to korespondencja podtrzymująca nadzieję na lepszą przyszłość oraz zawierająca prośby o porady w sprawie prac gospodarskich. Niemniej śmierć jest wszechobecna i środowisko chłopskie płaci ogromną cenę w czasie wojny. Stąd wielka liczba wdów i tzw. białych wdów, tzn. panien, których przyszli mężowie polegli. Ludzkie losy się komplikują i po wojnie wzmaga się fenomen migracji do miast.

\section{A jaka była sytuacja Francuzek w środowiskach miejskich?}

F. T.: Ważnym jest, by pamiętać, że kobiety nie stanowią jednolitej grupy, gdyż dzielą się ze względu na przynależność klasową, ale także ze względu na wiek, religię, pochodzenie narodowe, miejsce zamieszkania. Moja książka została opublikowana w 1986 roku w serii „Kobieta w czasie...”, dlatego w tytule jest użyta liczba pojedyncza. Przygotowując nową, poszerzoną wersję, u innego wydawcy w roku 2013, zażyczyłam sobie zmiany w tytule na liczbę mnogą (Les femmes au temps de la guerre de 14 - Kobiety w czasie wojny roku 1914)2. Trzeba najpierw podkreślić, że podczas wojny istnieją dwie Francje. Z jednej strony jest dziesięć departamentów na północy i wschodzie kraju, których ludność doznała inwazji i towarzyszących jej aktów przemocy (także przemocy seksualnej), a następnie niemieckiej okupacji pociągającej za sobą terror administracyjny, grabieże, przymusową pracę. $\mathrm{Z}$ drugiej strony pozostaje szeroki obszar poza terenem działań wojskowych, gdzie wojna może wydawać się odległa i gdzie niedobory nie są bardzo odczuwalne, nawet w ostatnich latach konfliktu. Kobiety z dobrze sytuowanych środowisk uprawiają jeszcze intensywniej niż przed wojną filantropię i mobilizują się w akcje solidarności (na rzecz żołnierzy, uchodźców, sierot, biednych rodzin), bądź też zatrudniają się ochotniczo jako pielęgniarki w szpitalach Czerwonego Krzyża. Po trudnym okresie bezrobocia z powodu destabilizacji ekonomicznej na początku konfliktu (nic nie było przygotowane, bo wojna miała trwać krótko), kobiety ze środowisk robotniczych znajdują pracę, a niektóre gospodynie domowe i młode dziewczyny odpowiadają na apel mobilizacji wszystkich sił w celu naprawienia gospodarki i zaopatrywania frontu. W czasie wojny dochodzi do przepływu kobiecej siły roboczej z sektorów tradycyjnie żeńskich i źle opłacanych (przemysł tekstylny, zwłaszcza odzieżowy) do sektorów mieszanych lub męskich, jak metalurgia i przemysł chemiczny, które przestawiają się na produkcję na potrzeby wojskowe. Po zawieszeniu praw socjalnych na czas konfliktu, praca w tych sektorach jest intensywna i niebezpieczna, ale lepiej płatna. Kobiety stają się też bardziej widoczne w przestrzeni publicznej, gdyż zastępują powołanych do wojska mężczyzn, pracują jako listonoszki, kelnerki, dostawczynie węgla, urzędniczki bankowe i administracyjne, tramwajarki, kontrolerki biletów. Ówcześni ludzie używają chętnie słowa „zastępczynie”, jest to bowiem termin wyrażający charakter tymczasowy sytuacji. Zresztą mogłam ustalić, że w okresie największego nasilenia zatrudnienia kobiet podczas wojny (koniec roku 1917 - początek 1918) personel żeński w przemyśle i handlu przekracza o dwadzieścia procent stan z roku 1914. Ten wskaźnik wzrostu, który mierzy dodatkowy nakład pracy kobiet w czasie wojny, jest niski, ponieważ Francuzki, w tym także mężatki, liczniej pracowały poza domem przed rokiem 1914 niż ich europejskie sąsiadki.

\footnotetext{
2 Zob. Thébaud, Françoise 2013. Les femmes au temps de la guerre de 14. Paris: Payot \& Rivages.
} 
Miliony kobiet przechodzą jednak wspólnie przez doświadczenie samotności, trwożnego oczekiwania na wieści z frontu, żałoby.

\section{Podczas I wojny propaganda francuska kładła duży nacisk na macierzyństwo. Dlaczego to było tak ważne?}

F. T.: Francja była pierwszym, biorąc pod uwagę chronologię i zakres zjawiska, w Europie krajem „maltuzjańskim”, z bardzo dużym spadkiem liczby urodzeń od lat siedemdziesiątych XIX wieku. Przed rokiem 1914 powstają ligi pronatalistyczne, które walczą o przyjęcie przez władze rygorystycznej polityki wspierającej wzrost poziomu rozrodczości i wielodzietne rodziny. Organizacje te podkreślają niebezpieczeństwo, jakie stanowią sąsiednie Niemcy z ich szybko rozmnażającym się społeczeństwem. Wojna, która w końcowym rozrachunku spowoduje śmierć 1400000 żołnierzy i 300000 cywilów, nie licząc rannych i deficytu urodzeń, uwiarygadnia ich tezy. Propaganda kładzie więc nacisk na obowiązek kobiet, jakim jest rodzenie dzieci, czyli przyszłych żołnierzy. Niektórzy mówią nawet o kobiecym „podatku krwi”, gdyż należy ofiarować swą zdolność rozrodczą, a czasem nawet życie, tak jak mężczyźni przelewający swoją krew na polu bitwy.

Dlaczego po Wielkiej Wojnie konserwatywny model podziału ról żeńskich i męskich został odtworzony?

F. T.: Wojna, która oddziela mężczyzn od kobiet i przypisuje im przeciwne role, nie wydaje mi się okolicznością sprzyjającą ewolucji koncepcji męskości i żeńskości. Okres powojenny naznaczony jest kultem żałoby i poczuciem długu wobec żołnierzy. Stowarzyszenia kombatantów chcą odgrywać rolę polityczną i moralną. Ci, którzy przeżyli, chcą odnaleźć kobiety w tym miejscu, gdzie je pozostawili, wyjeżdżając na wojnę, a nie kobiety zaopatrzone w jakieś nowe prawa alba pracujące na stanowiskach przewidzianych dla mężczyzn. We Francji wojna także uwierzytelniła pronatalizm. Społeczeństwo oczekuje od kobiet, że odnowią one liczebność ludności kraju. W latach 1920 i 1923 zostają przyjęte ustawy zakazujące antykoncepcji i usuwania ciąży. Z punktu widzenia kulturowego wojna umocniła dychotomię mężczyzna / kobieta, żołnierz / matka.

\section{Czy można zatem stwierdzić, że wojna zmieniła istotnie sytuację Francuzek?}

F. T.: Wylano już dużo atramentu w dyskusji o tym, czy I wojna odegrała rolę emancypacyjną. Odpowiedź musi być zniuansowana. Opowiadam się po stronie historyczek i historyków, którzy stwierdzają, że raczej „nie, ale...”, niż „tak, ale...”. Powróciłam do tego pytania, w formie syntezy, w konkluzji drugiego wydania mojej książki w roku 2013. Nie ulega wątpliwości, że wojna zmodyfikowała przebieg indywidualnych losów, czasem w kierunku emancypacji, zwłaszcza w przypadkach dziewcząt ze środowisk mieszczańskich, które miały od młodego wieku podejmować odpowiedzialność, kształcić się, zdobyć zawód, co więcej - zdobywać nowe zawody w sektorze usług, który rozwija się i feminizuje. Są też dziewczęta, które porzucają wieś, by poznać światła wielkiego miasta. Ale dla większości kobiet, szczególnie matek, wojna była przede wszystkim okresem wyjątkowego znoju i ciężkich doświadczeń (samotność, żałoba, trudności materialne). Ponadto powrót żołnierzy rannych, okaleczonych, straumatyzowanych psychicznie nie zawsze jest łatwy i stwarza bolesne sytuacje rodzinne. Teza o roli emancypacyjnej wojny opiera się na dwóch argumentach: uzyskanie prawa wyborczego i postać chłopczycy. Otóż, niektóre kraje po za- 
kończeniu konfliktu przyznają kobietom prawo wyborcze, ale nie jest to przypadek Francji ani Włoch. Postać chłopczycy odnosi się do pewnego stylu w modzie. Krótsze spódnice, ubrania bardziej luźne, brak gorsetu - to wszystko rzeczywiście nadaje większej swobody ruchów kobiecemu ciału. Do tego dochodzi moda na krótkie włosy, fryzura bob. Tak jak w powieści Wiktora Margueritte’a Chłopczyca3. Książka, wydana w roku 1922, opowiada o przygodach młodej dziewczyny, która przeżywszy rozczarowanie swoim narzeczonym, oddala się od konwenansów środowiska mieszczańskiego, postrzeganego jako świat hipokryzji. Próbuje różnych zajęć, przeżywa wiele doświadczeń seksualnych, także z kobietami, oddaje się przyjemnościom nocnego życia i „sztucznych rajów” ", by stopniowo odkryć „uzdrawiające szczęście” dzięki miłości mężczyzny o wielkim sercu - kombatanta, pacyfisty, którego planuje poślubić i mieć z nim dzieci. Według autora, postępowego powieściopisarza, któremu odebrano Legię Honorową, książka miała być „umoralniającą bajką". Jednakże powieść została uznana za pornograficzną i odniosła sukces dzięki atmosferze skandalu. Jako prawdziwa metafora upadku obyczajów, o których mowa w wielu tekstach z tamtej epoki, chłopczyca nie jest postacią pozytywną. Niemniej moda „na chłopczycę” demokratyzuje się i szokuje coraz mniej. Również w latach dwudziestych, w wyniku dysproporcji pomiędzy płciami spowodowanych wojną, jest coraz więcej niezamężnych aktywnych i niezależnych kobiet. Jednak często są one bardziej rozsądne niż bohaterka powieści Wiktora Margueritte'a.

\section{Jaka była sytuacja wdów po wojnie we Francji?}

F. T.: We Francji jest wówczas około 600000 wdów. Jedna trzecia spośród nich ponownie wychodzi za mąż w ciągu lat dwudziestych. Pobierają one zasiłek (który przestaje być wypłacany w przypadku wyjścia za mąż), korzystają z zarezerwowanych dla nich miejsc pracy. Muszą układać sobie życie pod kontrolą zewnętrzną, ale ich sytuacja społeczna jest bardzo zróżnicowana, zależnie od wpływu własnej rodziny, rodziny poległego męża oraz zależnie od ich kwalifikacji zawodowych. Są one też postaciami otoczonymi czcią, których moralność jest kontrolowana.

Czy ruch feministyczny walczył o prawa kobiet podczas wojny? Jak, według Pani Profesor, można wytłumaczyć fakt, że $w$ Wielkiej Brytanii prawo wyborcze zostało przyznane kobietom jeszcze w czasie trwania wojny, a we Francji dopiero w roku 1944?

F. T.: W przededniu wojny ruch feministyczny we Francji jest dobrze zorganizowany, zwłaszcza wokół trzech stowarzyszeń: Narodowej Rady Kobiet Francuskich (Le Conseil National des femmes françaises - CNFF, należącej do Międzynarodowej Rady Kobiet), Ligi na Rzecz Praw Kobiet (La Ligue pour le droit des femmes), Francuskiej Unii na Rzecz Praw Wyborczych dla Kobiet (L’Union française pour le suffrage des femmes, utworzonej w roku 1909, należącej do Międzynarodowego Stowarzyszenia na Rzecz Praw Wyborczych dla Kobiet). Tak jak w innych krajach świata, walka o prawo wyborcze jest na porządku dziennym. Działaczki francuskie myślały, że będą mogły głosować w wyborach samorządo-

3 Zob. Margueritte, Wiktor 1991. Chłopczyca. Tłumaczenie Leopold Staff. Łódź: 86 Press. Tytuł oryginalny: La Garçonne.

${ }_{4}$ Termin (paradis artificiels), zaczerpnięty z pism Charles'a Baudelaire’a, na określenie środków odurzających. 
wych w roku 1916, do których nie doszło. Po wypowiedzeniu wojny, feministki francuskie, które deklarowały podczas kongresów międzynarodowych pacyfizm i internacjonalizm, $\mathrm{w}$ większości stają po stronie patriotyzmu, uważając, że chodzi o wojnę prawa z barbarzyństwem. Oddają się na służbę krajowi i zawieszają swoje żądania, argumentując, że w zaistniałej sytuacji mają tylko obowiązki do wypełnienia. Jednakże twierdzą one, że w ten sposób udowodnią, do czego kobiety są zdolne, i przygotują na przyszłość możliwość wywalczenia sobie praw. Począwszy od końca roku 1917, kwestia prawa wyborczego dla kobiet ponownie wysuwana jest na pierwszy plan. Inaczej niż miało to miejsce w przypadku obywatelek w innych krajach europejskich i w Stanach Zjednoczonych, Francuzki nie otrzymują praw politycznych po zakończeniu konfliktu. Pełna sprzeczności debata na ten temat miała miejsce w Izbie Deputowanych w maju 1919 roku i zakończyła się pozytywną decyzją, ale sprzeciwił się temu Senat. Ten scenariusz (pozytywne głosowanie deputowanych, odmowa senatorów) powtarza się pięciokrotnie w latach dwudziestych i trzydziestych, mimo zaangażowania sufrażystek. Przyznaniu praw wyborczych dla kobiet sprzeciwia się prawica (która uważa, że miejsce kobiet nie jest na scenie politycznej) i, w jeszcze większej mierze, laicka centro-lewica, tzn. Partia Radykalna, wielkie ugrupowanie w czasach Trzeciej Republiki, dominujące w Senacie. Partia Radykalna obawia się konserwatywnych głosów kobiet, które postrzegane są jako zbyt uległe wobec Kościoła katolickiego. Według tego ugrupowania wyborczynie stanowiłyby zagrożenie dla Republiki, której należy przypomnieć, że jej istota definiuje się w opozycji do Kościoła. W roku 1944 zgromadzenie narodowe utworzone przez ruch oporu, które nie zostało powołane w wyniku wyborów i w którego skład wchodziło mało członków dawnej Partii Radykalnej, przegłosowało poprawkę zgłoszoną 24 marca w Algierze przez komunistę Fernanda Greniera: „kobiety będą wyborczyniami i będą wybierane na tych samych warunkach, co mężczyźni”. Kobiety głosują po raz pierwszy w czasie wyborów samorządowych w kwietniu i maju 1945 roku.

Jest Pani założycielką czasopisma „Clio. Femmes, Genre, Histoire” i stowarzyszenia Mnémosyne. Czy może Pani Profesor opisać kontekst intelektualny, kulturowy i naukowy, w którym rodzily się te inicjatywy, i scharakteryzować ich cele?

F. T.: Rzeczywiście byłam inicjatorką utworzenia w roku 1995 czasopisma, które w tamtym czasie nosiło tytuł „Clio. Histoire, Femmes et Sociétés”. Termin „genre” (gender) był słabo znany i mało używany we Francji przed rokiem 2000. Kontekst był taki: z jednej strony ukazanie się w latach 1991-1992 pięciu tomów serii „Histoire des femmes en Occident” („Historia kobiet na Zachodzie”) - byłam redaktorką ostatniego tomu, poświęconego XX wiekowi ${ }^{5}$ - uprawomocniło intelektualnie badania, które przez długi czas były podważane we Francji i uważane za nienaukowe; z drugiej strony, po pionierskich inicjatywach w Stanach Zjednoczonych kobiecych czasopism historycznych, kolejne czasopisma pojawiają się na początku lat dziewięćdziesiątych w różnych krajach europejskich: „Women’s History Review” i „Gender \& History” w Wielkiej Brytanii, „Sextant” w Belgii, „L’Homme. Zeitschrift für Geschichtswissenschaft“ w Austrii, „Arenal. Revista de historia de las mujeres" w Hiszpanii. Utworzenie czasopisma francuskiego było środkiem pozwalającym na instytucjonalną organizację pola badawczego i na umocnienie jego wiarygodności. Chodziło z jednej strony o umożliwienie publikowania prac francuskich i wykazania

5 Zob. Thébaud, Françoise (red.) 1992. Histoire des femmes en Occident. Le XXe siècle. T. 5. Paris: Plon. 
ich wartości naukowej, a z drugiej strony o udostępnienie we Francji wyników badań zagranicznych. To wszystko działo się przy małym wsparciu instytucji i przy wielkim nakładzie pracy wolontariackiej entuzjastycznego zespołu, w pierwszej fazie tylko kobiecego, później mieszanego. Po dwudziestu dwóch latach i czterdziestu pięciu numerach można mówić o success story. W roku 2012 francuskie Narodowe Centrum Badań Naukowych (Centre National de la Recherche Scientifique - CNRS) doceniło wysoki poziom czasopisma, przyznając mu etat sekretarza redakcji i subwencję na publikację, począwszy od roku 2013, elektronicznej wersji „Clio” w języku angielskim. Jeszcze nie wiemy, czy ten program przewidziany na pięć lat będzie kontynuowany, niemniej było to bardzo wzbogacające doświadczenie dla czasopisma. Z tej okazji zmieniliśmy wydawcę i zmodyfikowaliśmy podtytuł, dodając termin „gender”: „Clio. Femmes, Genre, Histoire” - „Clio. Women, Gender, History”. Jeśli chodzi o stowarzyszenie Mnémosyne - na rzecz rozwoju historii kobiet i gender, jest ono francuską sekcją Międzynarodowej Federacji na rzecz badań z zakresu historii kobiet. Zostało ono utworzone w roku 2000 w celu dołączenia się do tej struktury międzynarodowej i zorganizowania we Francji pola badawczego. Jego działania szybko się rozwinęły: rozpowszechnianie informacji poprzez wydawanie rocznika, a następnie poprzez stronę internetową, organizacja sesji naukowych, pomoc dla młodych badaczy i badaczek poprzez ufundowanie przyznawanej co roku nagrody za najlepszą pracę magisterską (nagroda pieniężna i publikacja), utworzenie czasopisma elektronicznego „Genre \& Histoire”, opracowanie narzędzi przekazu historii kobiet i gender do nauczania na poziomie szkól średnich. W tym też celu Mnémosyne opublikowało dwie prace adresowane do nauczycieli i nauczycielek gimnazjów i liceów: w roku 2010 La Place des femmes dans l'histoire. Une histoire mixte (Miejsce kobiet w historii. Historia mieszana) - pozycja wprowadzająca do nauczania kwestie kobiet i gender (publikacja we współpracy z wydawnictwem Belin); w 2017 L'Europe des femmes, XVIII ${ }^{e}-X X I^{e}$ siècles (Europa kobiet od XVIII do XXI wieku) - zbiór przetłumaczonych na francuski ponad siedemdziesięciu tekstów napisanych $\mathrm{w}$ różnych językach europejskich (we współpracy z Genre du Laboratoire LabEX „Écrire une histoire nouvelle de l'Europe") ${ }^{6}$.

W nowym wydaniu Pani pracy Écrire l'histoire des femmes et du genre (Pisanie historii kobiet $\mathrm{i}$ ptci) ${ }^{7}$, z roku 2007, komentując rozwój badań na historią kobiet i gender od końca lat 1990, podkreśla Pani Profesor wymiar komparatystyczny tej gałęzi historiografii. W odniesieniu do studiów poświęconych kobietom podczas Wielkiej Wojny, jakie wyzwania i cele stają przed komparatystami?

F. T.: Wspomniany tu wymiar porównawczy jest podwójny. Z jednej strony, badania genderowe zachęcają, aby nie studiować kondycji kobiet w oderwaniu, a w perspektywie porównawczej poprzez zestawienie sytuacji kobiet i mężczyzn i obserwację rozumienia pojęć męskości i kobiecości. Z drugiej strony chodzi o porównanie różnych sytuacji narodowych, aby wydobyć ich znaczenie poprzez badanie podobieństw i różnic. Podjęłam próbę takiego podejścia porównawczego w rozdziale poświęconym Wielkiej Wojnie we wspomnianym wyżej ostatnim tomie „Histoire des femmes en Occident”, opublikowa-

6 Zob. Dermenjian, Geneviève, Irène Jami, Annie Rouquier et Françoise Thébaud (red.) 2010. La place des femmes dans I'histoire. Une histoire mixte. Paris: Belin; Le Gac, Julie et Fabrice Virgili (red.) 2017. L'Europe des femmes, $X V I I I^{e}-X X l^{e}$ siècle. Paris: Perrin.

7 Zob. Thébaud, Françoise 2007. Écrire l'histoire des femmes et du genre. Lyon: ENS. 
nym w roku 1992. Ten rozdział wydaje mi się nadal bardzo istotny, ale też widzę dzisiaj pewne braki: nasz Zachód w roku 1992 obejmował tylko wielkie kraje Europy Zachodniej i Ameryki Północnej. Dzisiaj byłoby możliwym i koniecznym wzięcie pod uwagę małych krajów, jak Belgia, Szwajcaria czy Grecja, gdzie zostały w tym zakresie przeprowadzone liczne badania. Chodzi zwłaszcza o prace Eliane Gubin (Wolny Uniwersytet Brukselski), Brigitte Studer (Uniwersytet Berneński), Efi Avdela (Uniwersytet Kreteński). Należałoby też włączyć Europę Środkową i Wschodnią, stanowiącą blok wschodni pomiędzy rokiem 1945 i początkiem lat dziewięćdziesiątych, której wcześniejsza historia długo pozostawała słabo znana i mało nauczana we Francji. Tekst z roku 1992 nie brał też pod uwagę historii mężczyzn i kobiet z terenów kolonialnych. We Francji, mimo jej przeszłości kolonialnej, badania na temat tych obszarów, w zakresie historii ogólnej i tym bardziej historii kobiet i płci, pojawiły się bardzo późno. Jeśli chodzi o badania nad Wielką Wojną we francuskim imperium kolonialnym i zwłaszcza nad doświadczeniem - w tym kontekście - kobiet, pozostaje tu jeszcze wiele do zrobienia.

Oprócz podejść komparatystycznych, jakie są obecnie, w ocenie Pani Profesor, inne możliwe kierunki badań kulturowych na temat I wojny?

F. T.: Teraz widzę dwa takie kierunki. Po pierwsze badania nad wrażliwością poprzez analizę osobistych archiwów, które są liczne, ale często przechowywane przez rodziny (listy, dzienniki osobiste pisane w czasie wojny, zredagowane później autobiografie). Takie podejście pozwala zarysować historię życia wewnętrznego w czasie konfliktu i po jego zakończeniu. Po drugie - badania transnarodowe nad przepływem różnych elementów pomiędzy krajami mimo wszechpanujących szowinizmów.

W jednym z artykułów, w roku 2004 ${ }^{8}$, wykazała Pani Profesor wpływ wydarzeń w latach dziewięćdziesiątych w byłej Jugosławii na nowe postrzeganie historiograficzne I wojny. Wskazuje Pani, w tym kontekście, na odejście od problematyki emancypacji na rzecz kwestii przemocy. A co można powiedzieć o obrazie Wielkiej Wojny z dzisiejszej perspektywy? Czy widzi Pani Profesor współczesne nam czynniki polityczne i ideologiczne, które mogły wpłynąć na jeszcze inne podejścia historiograficzne i kulturoznawcze do problematyki I wojny?

F. T.: Tak, kwestia przemocy wojennej stała się pierwszoplanowa w badaniach historyków i historyczek, począwszy od lat dziewięćdziesiątych. Prowadzone są studia nad sponiewieranymi ciałami żołnierzy, m.in. tzw. gueules cassées, czyli ocaleńców powracających z frontu ze zdeformowanymi twarzami. Dotyczy to także badań nad traumami psychicznymi i następstwami ciążącymi nad życiem rodzin po wojnie, czy też nad przemocą seksualną i na tle płciowym, w tym gwałtami na kobietach dokonywanymi przez najeźdźcę bądź okupanta. Studia te wykazują, że wojna dla kobiet jest bardziej ciężkim doświadczeniem niż czynnikiem emancypującym. W konkluzji mojej książki, w wydaniu z roku 2013, zadałam pytanie, czy kwestia emancypacji kobiet nie jest zagadnieniem „zachodnim”, dotyczącym obszarów, które nie znalazły się pod okupacją i nie ucierpiały zbytnio z powodu niedostatków, a które szybko odzyskały równowagę w okresie powojennym. Jest to jednak nadal

8 Zob. Thébaud, Françoise 2004. „Penser la guerre à partir des femmes et du genre: I'exemple de la Grande Guerre". Astérion 2: 179-194. 
zagadnienie heurystyczne. Stanowi ono element badań nad następstwami wojny i wykracza poza wydarzenia, które mają miejsce bezpośrednio po zakończeniu działań zbrojnych. Zagadnienie to nakłania do zgłębienia problemu równowagi pomiędzy płciami czy porządku genderowego, który zostaje odtworzony po wojnie.

\section{Jak thumaczy Pani Profesor zjawisko tak intensywnego powrotu Wielkiej Wojny w kulturze francuskiej w ciągu ostatnich dekad?}

F. T.: Wielka Wojna nigdy nie była nieobecna w kulturze francuskiej od zakończenia konfliktu. Jest wojną, która dotknęła większość rodzin. 11 listopada pozostaje dniem wolnym od pracy. Pomniki poległych wznoszone w latach dwudziestych, obecne prawie we wszystkich francuskich gminach (w liczbie 36000 ) pozwoliły na wyrycie w kamieniu niekończących się list poległych żołnierzy. Dotyczy to zwłaszcza obszarów wiejskich, które zostały wyludnione w czasie wojny. Jest jednak prawdą, że co do niektórych aspektów (takich jak okupacja, opór, niedostatki) pamięć zbiorowa o II wojnie przykryła, po roku 1945, pamięć o Wielkiej Wojnie. Powrót I wojny jest dziełem dokonanym przez pokolenie wnuków. Z jednej strony, historycy i historyczki podjęli na nowo refleksje nad konfliktem, przenosząc punkt ciężkości (na historię kobiet, ale także na historię kulturową w przypadku muzeum Historial de la Grande Guerre de Péronne w Pikardii, którego współzałożycielem jest Stéphane Audoin-Rouzeau $)^{9}$. Z drugiej strony, wnuki odkrywają, przy okazji śmierci członków ich rodzin albo w momencie dziedziczenia spadku, zapiski wojenne dziadków i pragną je publikować. Historycy i krytycy komentowali te teksty, dzięki czemu zjawisko się rozprzestrzeniło. Sukces, od roku 2013, różnego rodzaju inicjatyw naukowych i upamiętniających dziedzictwo, z okazji setnej rocznicy Wielkiej Wojny, świadczy o zainteresowaniu tym wydarzeniem historycznym i jednocześnie utrwala pamięć o nim. W roku 2012 została powołana Misja na rzecz stulecia I wojny. Jest to program rządowy mający na celu koordynację wszystkich przedsięwzięć upamiętniających o charakterze prywatnym i publicznym oraz upowszechnianie wiedzy na temat konfliktu, poprzez utworzenie elektronicznej bazy danych. Wśród tych inicjatyw warto wymienić dwie akcje zbierania dokumentacji zrealizowane w listopadzie 2013 i w listopadzie 2014 roku. Pierwsza z nich była związana z szerzej zakrojonym projektem europejskim „Europeana 1914-1918”, polegającym na gromadzeniu i udostępnianiu wszelkiego typu dokumentów związanych z Wielką Wojną. W 2013, jak i w 2014 roku, zaproszono Francuzów do dzielenia się wspomnieniami ich przodków z czasów I wojny, żołnierzy i cywilów. Ponad 20000 osób odpowiedziało na ten apel i udało się do 150 oddziałów archiwów biorących udział w projekcie - 1600 zbiorów archiwalnych zostało w ten sposób powierzonych lub ofiarowanych i około 325000 dokumentów zostało zdygitalizowanych. Są wśród nich listy do rodziców, do narzeczonej albo żony, zapiski osobiste, szkice i rysunki, dyplomy, medale, niesamowite przedmioty wyprodukowane w okopach. Te dwa przedsięwzięcia zostały przeprowadzone we wspólpracy z Ministerstwem Edukacji Narodowej, co pozwoliło na ich wykorzystanie w procesie dydaktycznym. Wielka Wojna jest wyraźnie obecna w dzisiejszej kulturze Francji.

\footnotetext{
9 Na temat muzeum w Péronne i prac Stéphane'a Audoina-Rouzeau zob. artykuł Współczesne badania poświęcone I wojnie światowej w Wielkiej Brytanii i Francji - perspektywa kulturoznawcza Anny Branach-Kallas i Piotra Sadkowskiego w tym numerze „Litterariów Copernicanów”.
} 